\title{
Editorial
}

\section{On talc, tremolite, and tergiversation}

Asbestos is a generic term applied to several silicates that can be separated into long, thin fibres and woven into cloth. The minerals that constitute the various types of asbestos also exist as non-asbestiform variants. Some of these minerals have a different name attached to them according to whether they are asbestiform or non-asbestiform. Thus the nonasbestiform counterpart of chrysotile is antigorite. Chrysotile, crocidolite, and amosite have specific names for their non-asbestiform counterparts but anthophyllite tremolite, and actinolite asbestos do not.

In 1986 the United States Occupational Safety and Health Administration promulgated a new asbestos standard that reduced the acceptable exposure concentration for all types of asbestos to $0 \cdot 2 \mathrm{f} / \mathrm{ml} .{ }^{1}$ This standard defined asbestos as mineral fibres composed of crystalline hydrated silicates with a length of $5 \mu \mathrm{m}$ or longer and an aspect ratio greater than 3:1. The standard recognised the distinction between asbestiform and non-asbestiform types of mineral, but the methods of differentiating the two forms were not specified. It was stated, however, that the non-asbestiform variants of three amphibole minerals would be treated as if they were asbestos. A standard that regulates non-asbestiform anthophyllite, tremolite, and actinolite in the same manner as their asbestiform counterparts assumes that they constitute as great a hazard as exposure to asbestos.

The manner in which fibres induce mesothelioma or lung cancer is unknown. Wagner first showed that mesothelioma could be induced by the intrapleural installation of free fibres. ${ }^{2}$ No insight into the biological activity of common non-asbestiform tremolite resulted from these experiments. Subsequently Wagner et al showed that one form of asbestiform tremolite injected into the pleural cavity of rats produced mesotheliomas, whereas an equal dose of two non-asbestiform tremolites did not. ${ }^{3}$ Several non-asbestiform fibres, including glass, were capable of inducing mesotheliomas provided the diameter of the fibres was less than $0.5 \mu \mathrm{m}$, but nonasbestiform actinolite, biotite, and talc did not produce tumours. ${ }^{4} \mathrm{~A}$ relation was found between fibre size and the development of mesothelioma and it was concluded that the fibrous structure was the pre-eminent influence in the induction of malignant tumours of the pleura. Later, Stanton and Wrench carried out experiments using various forms of asbestos-namely, fibrous glass, and the fibrous earths including attapulgite and sepiolite. ${ }^{5}$ The various agents were inoculated into the pleural cavity. It seemed that carcinogenicity was related to dimensional distribution of the fibres with those longer than $8 \mu \mathrm{m}$ and width $0.25 \mu \mathrm{m}$ or less being the most hazardous. ${ }^{6}$ Although this hypothesis has much in its favour, at the present time it remains unproven. The relative infrequency of mesothelioma in man is probably best explained by the fact that few fibres of the required length and width find their way to the pleura, and this is especially true for chrysotile. Stanton $e t \mathrm{al}^{7}$ reported on further studies in rats in which both asbestiform and non-asbestiform minerals were used including samples of talc containing non-asbestiform tremolite. Asbestiform tremolite induced tumours in virtually $100 \%$ of the treated rats but non-asbestiform tremolite proved non-carcinogenic. Smith et $a l^{8}$ carried out similar experiments, giving two different doses to hamsters. Again, asbestiform tremolite was a powerful carcinogen but the animals that were injected with non-asbestiform tremolite remained free of tumours. More recently Addison and Davis injected different forms of asbestiform and non-asbestiform tremolite into the peritoneal cavities of rats. A high proportion of respiratory tumours was found in the group given tremolite asbestos but not in the group treated with non-asbestiform tremolite. ${ }^{9}$ Other studies have produced similar findings. ${ }^{1011}$

Several investigations have been carried out among workers exposed to cummingtonite grunerite (the non-asbestiform analogue of amosite). For example, McDonald et al evaluated the mortality of gold miners with long tenure of employment. ${ }^{12}$ Overall, excess deaths in the cohort were from pneumoconiosis, tuberculosis, and heart disease; non-malignant respiratory disease showed a trend with estimates of exposure but no excess or trend was evident for cancers of the respiratory system. Brown et al studied gold miners who had worked underground at the same mine for at least one year and found similar results. ${ }^{13}$ Cooper et al studied taconite 
miners employed for at least three months and found no association between respiratory cancer and tenure of work or latency. ${ }^{14}$ Central to the issue of carcinogenicity of asbestos analogues are the studies on talc miners and millers in New York. A proportionate mortality study of talc workers was first published by Kleinfeld et al in $1967^{15}$ and, later, for the same workers in $1974 .{ }^{16}$ The study group consisted of all talc workers employed in 1940 with 15 or more years exposure. There were 108 deaths including 12 attributed to lung cancer, one to fibrosarcoma of the pleura and one to peritoneal mesothelioma. The proportionate mortality for respiratory cancer was $12 \%$ compared to $3.7 \%$ expected. The excess was seen only in the 60-79 age group and mainly in the period 1945-69. Although they give rise to suspicions, such small numbers are difficult to interpret without necropsy data, history of smoking, and environmental information. Brown et al conducted a retrospective cohort mortality study of 398 workers in one New York talc mine and mill from which bulk samples contained $30-60 \%$ tremolite and 5-15\% anthophyllite. The main findings were nine deaths from bronchogenic cancer (standard mortality ratio $(S M R)=270)$ and one likely unrelated mesothelioma. No histories of smoking were available, five of the lung cancer cases had been employed at the facility for one year or less, and four men had less than two months employment. The authors concluded that the working environment posed a significant risk for the development of lung cancer, likely due to exposure to tremolite in the talc. ${ }^{17}$ Stille and Tabershaw ${ }^{18}$ reported on a cohort of 655 workers employed at the same location as those studied by Brown et al during 1948-77. An analysis was performed separating the cohort into two strata: for those with prior employment, the SMR for cancer of the respiratory system was raised at 214 (based on only two deaths). As with that of Brown et al, ${ }^{17}$ this study had several limitations including the absence of data on cigarette smoking and no analysis of exposure by latency. The dichotomous analysis of cases with and without prior employment used to implicate other unknown work exposure is questionable. A further analysis of essentially the same data was performed by Lamm and coworkers and this gave similar results. ${ }^{19}$ These authors concluded that the evidence was not consistent with a significant risk of lung cancer as a result of exposure at the facility in question. ${ }^{18}{ }^{19}$ Gamble and Piacitelli ${ }^{20}$ updated the original cohort of talc workers from upstate New York. Their analysis added eight more years of follow-up to the study by Brown et al, ${ }^{17}$ an exposure by latency analysis, and a nested case-control study to account for possible confounding by smoking and other occupational exposures. The case-control study focused on 22 cases of lung cancer each matched with three controls on date of birth and date of hire and who must have survived the case. No. relation was seen between mortality from lung cance $\overrightarrow{\overrightarrow{\vec{F}^{\prime}}}$ and non-talc employment. When the data were stratified by smoking, the odds ratio decreased witls tenure and the trend analysis was significant. Th analysis showed a strong association between lun cancer and cigarette smoking and there appeared to be an inverse relation between exposure and the development of lung cancer. The authors have $\vec{D}$ acknowledged shortcomings in their analysis, but it is none the less far more complete than similar moro tality studies and provides an argument against $\$$ causal relation between lung cancer and exposure to̊ non-asbestiform tremolite.

In the United States, the Consumer Product है Safety Commission (CPSC) is charged with the control of unreasonable hazards or injuries resulting from consumer products. In late 1986, the CPSC was petitioned to ban limestone products with a tremolitecontent of more than $0.01 \%$. The petition was refused with a statement from the CPSC that "there is a clear mineralogical distinction between asbes $\stackrel{\text { }}{-}$ tiform minerals and non-asbestiform cleavage frag $\overrightarrow{\overrightarrow{0}}$ ments no matter whether the persistence and dimens sion of the so called fibres may be similar." If the sole information on the hazards of non-asbestiform tremolite was mineralogical, clearly caution would be advisable. The fact that non-asbestiform tremolite has failed to induce mesothelioma when injected int animals suggests, however, that it would be inapo propriate to treat all forms of tremolite as bein $\overrightarrow{\vec{g}}$ equally hazardous.

It is also interesting to note that the recen standards for air quality proposed by the Unite States Mine Safety and Health Administration's exclude the non-asbestiform variants of antho $\frac{\mathbb{3}}{3}$ phyllite, tremolite, and actinolite from the asbestos portion of their standard; it is suggested that the should be regulated under the proposed respirable mine dust standard, presumably at $5 \mathrm{mg} / \mathrm{m}^{3}$.

In summary, there is no evidence to suggest thap the non-asbestiform mineral counterparts of asbestos are carcinogens in animals. Although the results fror animal studies may not necessarily establish a lack of carcinogenicity for non-asbestiform amphiboles for humans under all exposure conditions, they dof suggest that if a risk is present, it is markedly less that that for asbestos. The studies on mortality of worker\& exposed to non-asbestiform cummingtonite grun erite are uniformly negative. Whereas early studies of talc workers from upstate New York showed excess death rates from respiratory malignancies, exposure to dust and cigarette smoking were not taken intō account; hence, the cause of the excess respirator $\vec{B}$ malignancy in these workers is highly speculativer Later studies suggest that other exposures may have been important factors in the rates of lung cancer seen. Lastly, the lack of a trend in a latency bo 
exposure analysis, a significant odds ratio for cigarette smoking, and an inverse relation between lung cancer and exposure when controlling for smoking have been noted. Thus the overall results argue convincingly against a causal connection between lung cancer and non-asbestiform tremolite.

Institute of Occupational Health and Safety, West Virginia University School of Medicine, Morgantown, WV 26506, USA

Chief, Chest Diseases Unit,

University Hospital,

London, Ontario, N6A 5A5, Canada

1 United States Department of Labor, Occupational Safety, and Health Administration. Occupational exposure to asbestos, tremolite, anthophyllite, and actinolite: final rules. Federal Register 1986;51 (No 119):22612-790. (29 CFR parts 1910 and 1926.)

2 Wagner JC. Experimental production of mesothelial tumours of the pleura by implantation of dusts in laboratory animals. Nature 1962;196:180-1.

3 Wagner JC, Berry G, Timbrell V. Mesothelioma in rats after inoculation with asbestos and other materials. $\mathrm{Br} J$ Cancer 1973;28:173-85.

4 Wagner JC, Berry G. Mesothelioma in rats following inoculation with asbestos. Br J Cancer 1969;23:567-81.

5 Stanton MF, Wrench C. Mechanisms of mesothelioma induction with asbestos and fibrous glass. J Natl Cancer Inst 1972;48:797-821.

6 Stanton MF, Layard M, Tegeris A, Miller E, May M, Kent E. Carcinogenicity of fibrous glass: pleural response in the rat in relation to fiber dimension. J Natl Cancer Inst 1977;58: 587-603.

7 Stanton MF, Layard M, Tegeris A, et al. Relation of particle dimension to carcinogenicity in amphibole asbestosis and other fibrous minerals. J Natl Cancer Inst 1981;67:965-75.

8 Smith WE, Hubert DD, Sobel HJ, Marquet E. Biologic tests of tremolite in hamsters. In: Lemen $R$, Dement JM, eds. Proceedings of the conference on occupational exposures to fibrous and particulate dusts and their extension into the environment. Dust and disease. Pathotoxicology. Park Forest South ILL: Pathodox Publishers, 1979:335-9.
9 Addison J, Davis JMG. A comparison of the carcinogenicity of six tremolites using the intraperitoneal injection assay in rats. Proceedings of the VIIth international pneumoconiosis conference. Pittsburgh: International Labor Office, 1988 (abstract) and Davis JMG, Addison J, McIntosh C, Miller B, Niven $\mathrm{K}$. Variations in the carcinogenicity of tremolite dust samples of differing morphology. Occupational Safety and Health Administrative hearings. Washington DC, May 1990. (Docket H-033-d No 22.)

10 Wagner JC, Chamberlain M, Brown RC, et al. Biological effects of tremolite. Br J Cancer 1982;45:352-60.

11 McDonnell JC, Rutter HA, Ulland BM, Moore JA. Chronic effects of dietary exposure to amosite asbestos and tremolite in F344 rats. Environ Health Perspect 1983;53:27-44.

12 McDonald JC, Gibbs GW, Liddell FDK, McDonald AD. Mortality after long exposure to cummingtonite-grunerite. Am Rev Respir Dis 1978;118:271-7.

13 Brown D, Kaplan SD, Zumwalde M, et al. Retrospective cohort mortality study of underground gold mine workers. In: Goldsmith DF, Winn DM, Shy CM, eds. Silica, silicosis, and lung cancer: controversy in occupational medicine. New York: Praeger, 1984:335-50.

14 Cooper WC, Otto Wong, Graebner R. Mortality of workers in two Minnesota taconite mining and milling operations. $J$ Occup Med 1988;30:663-7.

15 Kleinfeld M, Messite J, Kooyman O, Kaki MH. Mortality among talc miners and millers in New York State. Arch Environ Health 1967;14:663-7.

16 Kleinfeld M, Messite J, Kaki MH. Mortality experiences among talc workers: a follow-up study. J Occup Med 1974;16:345-9.

17 Brown DP, Dement JM, Wagner JL. Mortality patterns among miners and millers occupationally exposed to asbestiform talc. In: Lemen R, Dement JM, eds. Proceedings of the conference on occupational exposure to fibrous and particulate dusts and their extension into the environment. Dust and disease. Pathotoxicology. Peak Forest South ILL: Paradox Publishers, 1979:317-24.

18 Stille WT, Tabershaw IR. The mortality experience of upstate New York talc workers. J Occup Med 1982;24:480-4.

19 Lamm SH, Levine MS, Starr JA, Tirey SL. Analysis of excess lung cancer risk in short-term employees. Am J Epidemiol 1988;127:1202-9.

20 Gamble J, Piacitelli G. Personal communication, Mine Hazard Evolution and Technical Assistance (MHETA) draft report 1988 (NIOSH 86-012.) and Gamble J, Piacitelli G. Occupational Safety and Health Administration hearings. Washington DC, May 1990. (Docket H-033-d No 478-88.)

21 United States Department of Labor, Mine Safety, and Health Administration. Air quality chemical substances and respiratory protection standards; proposed rule. Federal Register 1989;54 (No 166):35760-852. (30 CFR part 56.)

\section{Correspondence and editorials}

The British Journal of Industrial Medicine welcomes correspondence relating to any of the material appearing in the journal. Results from preliminary or small scale studies may also be published in the correspondence column if this seems appropriate. Letters should be not more than 500 words in length and contain a minimum of references. Tables and figures should be kept to an absolute minimum. Letters are accepted on the understanding that they may be subject to editorial revision and shortening.

The journal now also publishes editorials which are normally specially commissioned. The Editor welcomes suggestions regarding suitable topics; those wishing to submit an editorial, however, should do so only after discussion with the Editor. 
of the general population of a western society will know that a serious bias must have been introduced.

The high degree of exposure in the referent group of Harrington et al may possibly reflect the average exposure of the working population in the West Midlands, but probably not the exposure of the general population; certainly not of the general population in other areas. The study of Harrington et al has confirmed that patients with glomerulonephritis are frequently exposed to organic solvents, but due to their choice of controls their finding is not conclusive.

UFFE RAVNSKOV

Brunnsgatan 6, $S-22360$ Lund, Sweden

1 Ravnskov U, Lunström $S$, Nordén $A$, Hydrocarbon exposure and glomerulonephritis: evidence from patients' occupations. Lancet 1983;ii:1214-6.

2 Harrison DJ, Thomson D, Macdonald MK. Membranous glomerulonephritis. J Clin Pathol 1986;39: 167-71.

3 Ravnskov U. Exposure to organic solvents-a missing link in poststreptococcal glomerulonephritis? Acta Med Scand 1978;203:351-6.

4 van der Laan G. Chronic glomerulonephritis and organic solvents. A case-control study. Int Arch Occup Environ Health 1980;47:1-8.

\section{Author's reply}

Ravnskov raises some interesting issues concerning our paper. $\mathrm{He}$ is, of course correct in pointing out, as we do, that our findings are inconclusive due to power considerations in the case-referent design. Unfortunately, however, he does not write from a totally unbiased position, given the fact that his studies are among those commented on in our discussion.

We did not "ignore" any of the relevant studies-indeed his work is cited as important and relevant. But it is too simplistic merely to add up studies and weigh them in some numeral balance of for or against. All published studies need to be assessed for their epidemiological strengths and weaknesses. When this more logical approach is used, most are found wanting, including ours.

The point about streptococcal and non-streptococcal glomerulonephritis is valid. The use of community referents may be "elementary" but it is methodologically difficult which is perhaps why most other studies eschew the device. That alone weakens such studies. Hospital based controls are universally recognised as inherently more biased than community based controls. In our paper we go to considerable lengths to point out that our results are inconclusive, an aspect which needs no further emphasis by Ravnskov. Nevertheless, it is clear to any unbiased observer that most of the published studies are seriously flawed. Ours may have low power but at least it avoids most of the weaknesses inherent in most of the other studies.

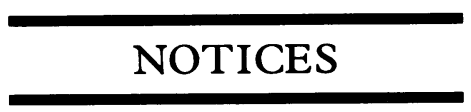

3rd Meeting of the International Neurotoxicology Association, Salsomaggiore Terme (Parma), Italy, 1-5 July, 1991.

The 3rd INA meeting will provide a forum for interdisciplinary exchanges between scientists involved in different areas of neurotoxicology, including experimental, clinical and epidemiological aspects, and covering a wide range of relevant information from neuropathology, neurochemistry, neurophysiology, neuroteratology, and neurobehavioural toxicology. Four symposia based on invited lectures will be arranged by the scientific committee. Unsolicited contributions will be presented as posters, which will be discussed during special sessions. Workshops on specific issues will also be organised. The preliminary programme includes subcellular and cellular mechanisms of neurotoxicity; neurotoxicity and ageing; developmental neurotoxicity; and screening for neurotoxicity in humans. For further information, contact: Dr A Mutti, Organising Secretary 3rd INA Meeting, Laboratory of Industrial Toxicology, University of Parma-Via Gramsci 14, I-43100 PARMA Italy.

International Symposium on Future Trends in the Changing Working Life, Finlandia Hall, Helsinki, Finland, 13-15 August 1991.

Many factors, including internationalisation, automation, raised level of education and training, aging of the population, and changes in values and attitudes will drastically change the nature of work in the next decade and into the 21st Century. The general objective of the Symposium is to facilitate the transfer of research to benefit the development of work and the quality of the working life in the future. To achieve this four major themes will be considered in plenary sessions-namely, work in an international environment, the quality of working life, work in the future, and human resources in work in the future. Particpants are welcome to present oral free communications or posters, or to participate in formal and informal discussions. The official language of the Symposium is English, with simultaneous translation into Finnish. For further information contact: Work in the 1990s International Symposium on Future Trends in the Changing Working Life, c/o Institute of Occupational Health, Suvi Lehtinen, Topeliuksenkatu 41 aA, SF-00250 Helsinki, Finland.

\section{Correction}

On talc, tremolite, and tergiversation (1990;47:505-507).

Owing to a copy editing error lines 3-5 second column page 505 are incorrect. They should read " . . . various forms of asbestos, fibrous glass, and the fibrous earths including attapulgite and sepiolite."' 